\title{
Sedimentation and subsidence history of the Lomonosov Ridge'
}

\author{
T.C. Moore ${ }^{2}$ and the Expedition 302 Scientists $^{2}$
}

\begin{abstract}
Chapter contents
Introduction $\ldots \ldots \ldots \ldots \ldots \ldots \ldots \ldots$

Methods ................. 1

Results .................... 2

Discussion .................. 3

Summary .................. 4

Acknowledgments.............. 5

References................... 5

Figures..................6 6
\end{abstract}

${ }^{1}$ Moore, T.C., and the Expedition 302 Scientists, 2006. Sedimentation and subsidence history of the Lomonosov Ridge. In Backman, J., Moran, K., McInroy, D.B., Mayer, L.A., and the Expedition 302 Scientists. Proc. IODP, 302: Edinburgh

(Integrated Ocean Drilling Program Management International, Inc.). doi:10.2204/

iodp.proc.302.105.2006

'Expedition 302 Scientists' addresses.

\section{Introduction}

During the first scientific ocean drilling expedition to the Arctic Ocean (Arctic Coring Expedition; Integrated Ocean Drilling Program Expedition 302), four sites were drilled and cored atop the central part of the Lomonosov Ridge in the Arctic Ocean at $\sim 88^{\circ} \mathrm{N}, 140^{\circ} \mathrm{E}$ (see Fig. F18 in the "Sites M0001-M0004" chapter). The ridge was rifted from the Eurasian continental margin at $~ 57$ Ma (Fig. F1) (Jokat et al., 1992, 1995). Since the rifting event and the concurrent tilting and erosion of this sliver of the outer continental margin, the Lomonosov Ridge subsided while hemipelagic and pelagic sediments were deposited above the angular rifting unconformity (see Fig. F7A in the "Sites M0001-M0004" chapter).

The sections recovered from the four sites drilled during Expedition 302 can be correlated using their seismic signature, physical properties (porosity, magnetic susceptibility, resistivity, and $P$ wave velocity), chemostratigraphy (ammonia content of pore waters), lithostratigraphy, and biostratigraphy. The lithostratigraphy of the composite section combined with biostratigraphy provides an insight into the complex history of deposition, erosion, and preservation of the biogenic fraction. Eventually, the ridge subsided to its present water depth as it drifted from the Eurasian margin. In this chapter, we compare a simple model of subsidence history with the sedimentary record recovered from atop the ridge.

\section{Methods}

The postrifting subsidence of the Lomonosov Ridge is assumed to follow the simple thermal cooling pathway that is a function of the square root of its postrifting age (Sclater et al., 1971). In applying this simple model, we assume that the initial rifting process ended by $54 \mathrm{Ma}$ and then thermal subsidence began. The subsidence constant used in the equation and the progressive increase in the sediment load was adjusted so that the sediment surface reached the modern water depth of the sites at "zero" age (Fig. F2). Sediment accumulation rates and simple Airy isostasy are used to estimate the amount of sediment loading on basement.

Errors in estimating paleowater depth of the recovered section using this model could derive from two main sources. First, the simple model developed by Sclater et al. (1971) is based on the depth versus age profile of oceanic crust that is believed to indicate a 
gradual cooling of that crust as it ages. Thus, its application to the subsidence of a rifted fragment of an outer continental margin is associated with some uncertainty-especially in the early stages of rifting, when the role of faulting, possible uplift, erosion, and early isostatic adjustment is unknown. In applying this model to the Lomonosov Ridge we assume that true thermal subsidence did not begin until 2-3 m.y. after initial rifting and after most of the immediate impact of tectonic adjustments had diminished.

The second source of error is associated with the estimates of paleowater depth and paleosea level. Paleowater depth estimates from the benthic fauna recovered from the base of the section only extend up to Core 302-M0004A-27X (estimated age $=\sim 54 \mathrm{Ma}$ ) and indicate an inner neritic to neritic depth environment. This qualitative term is usually thought to indicate very shallow to shallow water and is not usually associated with large error bars (i.e., $<100 \mathrm{~m}$ ). Quantitative estimates of paleosea level, however, have substantial errors associated both with the timing and the magnitude of sea level change (Miller et al., 2005)—especially in the older part of the Cenozoic and in preCenozoic times. Errors in estimated age of the sea level changes in the early Cenozoic could range from 0.5 to $1 \mathrm{~m}$.y., whereas errors in the magnitude of sea level changes could be $20-30 \mathrm{~m}$ or more.

\section{Results}

Paleomagnetic data combined with dinocyst stratigraphy suggest that the base of the Cenozoic section (the top of the rifting unconformity) lies near Core $302-\mathrm{M} 0004 \mathrm{~A}-35 \mathrm{X}$ and has an age of $\sim 56 \mathrm{Ma}$. Agglutinated benthic foraminifers indicate a neritic to inner neritic environment in Cores 302-M0004A-27X through $35 \mathrm{X}$ (i.e., from the base of the Cenozoic section up to the middle part of lithostratigraphic Unit 3 at 367 meters below seafloor) (see "Micropaleontology" in the "Sites M0001-M0004" chapter). The estimated age of this level is $\sim 54 \mathrm{Ma}$. The Paleogene section is barren of benthic foraminifers above this level. Assuming that postrifting thermal cooling led to subsidence beginning at $54 \mathrm{Ma}$ (i.e., somewhat after the reestablishment of deposition on the ridge), the model estimates 1-2 m.y. of subsidence would result in a basement deepening of a bit under $200 \mathrm{~m}$, during which time $\sim 40 \mathrm{~m}$ of sediment was added to the section. The upper part of lithostratigraphic Unit 3 (i.e., above Core 302-M0004A-27X) does not contain evidence of bioturbation or submillimeter-scale laminations seen in the lower part of the unit where benthic foraminifers are found (see "Lithostratigra- phy" in the "Sites M0001-M0004" chapter). This gradual transition indicates a deepening of the site into less well oxygenated waters in the lowermost part of the oceanic mixed layer. The subsidence model used here indicates that this part of the section was deposited in paleowater depths between $\sim 200$ and $\sim 350 \mathrm{~m}$ (Fig. F2). The paleosea level curve of Miller et al. (2005) indicates a lowstand at 53.5-54 $\mathrm{Ma}$, followed by a rapid rise to a maximum in sea level between 53 and $52 \mathrm{Ma}$. The magnitude of this sea level rise is estimated to be $90 \mathrm{~m}$ (Miller at al., 2005).

The very organic rich sediments of lithologic Unit 2 are estimated to have been deposited at paleowater depths from $\sim 350$ to $650 \mathrm{~m}$ (at the base of the Eocene-Miocene hiatus) (Fig. F2). This depth range is consistent with the presence of an intense oxygen minimum zone below the upper mixed layer of the Eocene Arctic Ocean. In the modern, ice-covered Arctic, strong eddy mixing carries waters off the shelf into the ocean basin proper and mixes down to $\sim 200$ $m$ (Aagaard and Carmack, 1989, 1994). In the Eocene, these eddies could have transported nutrient-rich, relatively freshwaters from the wide shelfal region of the Arctic out into the ocean basin. Here, high productivity and relative low oxygen bottom waters created the ideal environment for the production and preservation of laminated, organic-rich sediments. The paleowater depths estimated here, however, are not entirely consistent with the depositional environment interpretation based on the biostratigraphy (see "Micropaleontology" in the "Sites M0001-M0004" chapter). The planktonic assemblages preserved in the sediments are often described as being indicative of neritic or nearshore conditions, when in fact the Eocene shoreline was distant from the Lomonosov Ridge sites. This apparent discrepancy probably results from the very unusual environmental conditions of the Eocene Arctic, including highly productive, very brackish nearsurface waters. These are the typical environmental conditions of surface waters found in nearshore areas of more normal open ocean basins.

A major hiatus in deposition ( 30 m.y. in duration) separates the anoxic middle Eocene and older section from the overlying suboxic/oxic Neogene section. By the time sediment began to accumulate once again on the ridge in the Miocene, the sites on the ridge had subsided to $\sim 1000 \mathrm{~m}$ paleowater depth (Fig. F2), and they have subsided only another $\sim 200$ $\mathrm{m}$ since that time. The presence of this large hiatus in the sedimentary record on the Lomonosov Ridge, together with the shift from the gray (suboxic) sediments just above the hiatus to the brown (oxidized) sediments found higher in the section (above the top 
of Section 302-M0002A-44X-1, 95 cm ( 191 meters composite depth [mcd]) (see Fig. F5 in the "Sites M0001-M0004" chapter), lead us to speculate about what may have caused the hiatus. Did the ridge simply subside through an oxygen minimum zone to a depth at which an intense boundary current was active? Or were there marked changes in the vertical structure of the Arctic Ocean sometime during the time spanned by the hiatus that gave rise to such intense currents and changes in the oxygenation of the bottom waters?

\section{Discussion}

In the warm part of the early Eocene, the sea level was 30-100 $\mathrm{m}$ higher than the modern sea level (Miller et al., 2005); thus, there were likely shallowwater connections to the North Atlantic, North Pacific, and central Tethys (see Fig. F18 in the "Sites M0001-M0004" chapter). The hydrologic cycle may have been operating at a rate almost twice that of today (Bice and Marotzke, 2001) because of the higher global temperatures during the Eocene. Thus, freshwater flow from the surrounding continents into the Arctic was probably substantially higher than today, whereas saltwater flow into the Arctic may have been very restricted by the very shallow passages connecting the Arctic with other ocean basins. As the climate cooled during the middle and late Eocene, sea level fell and the exchange of deeper waters with the surrounding open ocean became even more difficult. Thus, the Arctic Ocean of the Eocene probably had a brackish upper mixed layer and a strong vertical density gradient controlled by salinity. Nearly all identified Eocene microfossils indicate brackish water conditions. The minor exception to this is a short interval in the middle Eocene (Cores 302-M0002A-48X and 49X; 44 Ma), in which a very few specimens of radiolarians are found. Radiolarians in the modern environment do not normally tolerate salinities less than $\sim 20 \%$ o (Boltovskoy et al., 2003).

Layering in the very dark gray (Eocene) sediments is generally in the form of very thin laminae. Near the bottom of Section 302-M0002A-46X-1, $112 \mathrm{~cm}$, there is a sharp change in layering and color. The 3 $\mathrm{cm}$ thick light gray layer at this level is overlain by centimeter-scale couplets of gray and dark gray that extend to nearly the top of the overlying core (Core 302-M0002A-45X). This sharp color break at the base of the gray layer is thought to mark the base of the hiatus separating middle Eocene from lower Miocene sediments (see "Timescale and sedimentation rates" in the "Sites M0001-M0004" chapter).
Layering of the couplets above the gray layer appears tilted with some crosscutting of individual packages. The thickness of the layers and the angle of tilt increase upsection. In individual packages of tilted layers, the upper layering appears to have cut across part of the underlying layers. As shown in the seismic reflection data taken near the sites (see Fig. F7B in the "Sites M0001-M0004" chapter), the seismic facies lying just above the Eocene section consists of high-frequency anastomosing reflections. Both the character of the sediments overlying the uppermost part of the Eocene section and their apparent seismic signature suggest a dynamic sedimentary environment with a "cut and fill" character, which might indicate migrating sediment waves (Hall, 1979). Currents that could create such an energetic environment include strong baroclinic or boundary currents (Aagaard and Carmack, 1994), tidal-driven turbulence on top of and around the ridge, and internal wave oscillation on a surface with a high-density gradient. The gray to dark gray couplets in Cores 302-M0002A-45X and 46X contain reworked microfossils together with some dinoflagellates and pollen grains that have a distinct Miocene affinity (see "Micropaleontology" in the "Sites M0001-M0004" chapter). The presence of late Eocene and Oligocene microfossils in this interval gives evidence that some upper Eocene and lower Oligocene sediments were deposited in the region; however, they were largely eroded and removed from the section cored. The presumed oldest age of Miocene, together with the color and organic content of these couplets, indicates that the deeper waters in the Arctic remained relatively low in oxygen until well within the Miocene. Above the couplets, a more uniform gray layer (containing pyrite nodules) extends upsection for $\sim 3$ $\mathrm{m}$ before there is a diffuse transition to brownish, more oxidized sediments in Section 302-M0002A$44 \mathrm{X}-1,95 \mathrm{~cm}$. The transition to the brown oxidized section is also marked by a disappearance of palynomorphs.

Even as the Lomonosov Ridge continued to sink and after the anoxic character of the sediments disappeared, millimeter-scale sand lenses in the more oxygenated part of the section suggest a continued turbulent winnowing of the sediment. Under these conditions, it is not surprising that the average sedimentation rate $(\sim 1-3 \mathrm{~cm} / \mathrm{k} . \mathrm{y}$.) is comparatively low for a hemipelagic section and that other hiatuses may be found within the Lomonosov Ridge section. Even so, the very large hiatus at the top of the (middle) Eocene interval is unusually pronounced and represents almost 30 m.y. of extremely low to nondeposition (see "Timescale and sedimentation rates" in the "Sites M0001-M0004" chapter). 
The gradual cooling of the global climate through the middle and late Eocene, together with the major global climatic cooling at the Eocene/Oligocene boundary (Zachos et al., 2001), was very likely to have impacted the Arctic as well. Even in a very brackish ocean, severe cooling (especially seasonal cooling) may have altered the vertical structure of the near-surface waters and promoted some shallow convection. In addition, there are at least two major tectonic events (Figs. F1, F2) that may have contributed to changes in the deeper Arctic waters:

- Rifting of the Yermak and Morris Jesup Plateaus at $\sim 33 \mathrm{Ma}$, and

- Opening of the Fram Strait to shallow-water flow between 10 and 15 Ma (Lawver, et al., 1990) (Fig. F2).

Rifting of the Yermak/Morris Jesup Plateaus was the necessary first step in offering a more open flow into and out of the Arctic Basin and is likely to have marked the tectonic linkage of spreading in the Arctic Ocean with that in the Norwegian-Greenland Sea (Talwani and Eldholm, 1977; Rona and Richardson, 1978; Myhre et al., 1992). Clearance of the edge of the European continental plate at $\sim 15 \mathrm{Ma}$ as it moved past northeastern Greenland left only the Yermak Plateau blocking the passage to deepwater flow between the Norwegian Sea and the Arctic Ocean. The opening of the Fram Strait to deep water flow is not believed to have taken place till the Yermak Plateau cleared the northeastern margin of Greenland around 7 Ma (Lawver, 1990). The subsidence of the Iceland-Faeroe Ridge around 15-19 Ma (Thiede and Eldholm, 1983; Thiede and Myhre, 1996; Wright and Miller, 1996; Wright, 1998) may have also played an important role in Arctic paleoceanography (Fig. F2), for it was only after both the Greenland-Faeroe Ridge and the Fram Strait became open to at least shallow-water flow that the relatively warm, salty surface waters of the North Atlantic could easily enter the Arctic Basin. Given the timing of these gateway openings, it seems most likely that the introduction of North Atlantic waters into the Arctic is associated with the shift from the gray (suboxic) sediments to the brown (oxidized) sediments found in and above the top of Core 302-M0002A44X ( 191 mcd) (see Fig. F5 in the "Sites M0001M0004" chapter).

The earliest appearance of Northern Component Waters (NCW) in the deep North Atlantic occurred at 19-20 Ma (Wright and Miller 1996; Wright, 1998). This could mark the time that the Greenland-Faeroe Ridge had subsided to a depth that allowed a vigorous exchange between the Norwegian Greenland Sea and the North Atlantic. However, we could also en- visage a somewhat earlier intrusion of some North Atlantic near-surface waters into the NorwegianGreenland Sea and then into the Arctic itself that led to convection within these basins and the development of strong boundary currents near a strengthened pycnocline. This may have slightly preceded sufficient deepening of the Greenland-Faroe Ridge that allowed a full exchange with the North Atlantic. The first extensive mixing of the salty North Atlantic waters with the fresher, colder Arctic waters would then have led to both a greater oxygenation of Arctic deep waters and nearly continuous NCW formation (Wright, 1998; Wright and Miller, 1996).

\section{Summary}

The Lomonosov Ridge was rifted from the Siberian continental margin sometime near 57 Ma. Tilting and erosion of the rifted blocks ended by $\sim 56 \mathrm{Ma}$ when hemipelagic sediment began above the rifting unconformity. The subsidence model used here assumes that subsidence of the ridge began $\sim 54 \mathrm{Ma}$ through cooling that followed the rifting phase. This simple subsidence model is generally consistent with lithologic and benthic foraminifer data that indicate a relatively shallow water (neritic) environment of deposition on the Lomonosov Ridge up until $~ 54$ Ma. Within the Paleogene section, suboxic conditions existed in ridge sediments as they subsided from $\sim 200$ to $350 \mathrm{~m}$ paleowater depth. Once the ridge reached paleowater depths greater than $\sim 350$ $\mathrm{m}$, anoxic sediments, rich in organic carbon and well-preserved microfossils, began to accumulate. These sediments and the estimated water depths at which they were deposited are consistent with the presence of a strong oxygen minimum zone.

The presence of the large middle Eocene to lower Miocene hiatus in the sections recovered from the Lomonosov Ridge marks a transition from an underlying anoxic to suboxic Paleogene section to a more oxic Miocene and younger section and marks a profound change in both the lithologic character and the fossil content of the sediments. The character of the bedding just above the Eocene section strongly suggests that this hiatus is associated with relatively strong currents that eroded, reworked, and redeposited upper Eocene, Oligocene, and perhaps Miocene sediments. It is not known whether this hiatus is primarily associated with the subsidence of the ridge into a depth zone dominated by strong currents or with the tectonic control on connections between the Arctic and the North Atlantic. In either case, the cooling of the global climate through the middle and late Eocene and into the Oligocene undoubtedly is linked to these changes. 
The fact that reworked dinocysts having a "Miocene aspect" appear within the gray, suboxic sediments just below the Miocene oxic section in lithostratigraphic Subnit 1/5 suggests that the shift to fully oxygenated deep waters in the Arctic did not take place till sometime in the Miocene. The earliest appearance of NCW in the deep North Atlantic occurred at 19-20 Ma (Wright and Miller 1996, Wright, 1998) and may mark the time that the Greenland-Faeroe Ridge had subsided to a depth that allowed a gradually more vigorous exchange between the Norwegian-Greenland Sea, the Arctic, and the North Atlantic.

\section{Acknowledgments}

In addition to all the wonderful collaboration the Expedition 302 party has experienced, the senior author would like to acknowledge the very useful comments of Tony Doré and Ken Miller, with a special thanks to Ken Miller for providing a copy of his new paleosea level curve.

\section{References}

Aagaard, K., and Carmack, E.C., 1989. The role of sea ice and other fresh water in the Arctic circulation. J. Geophys. Res., 94(C10):14485-14898.

Aagaard, K., and Carmack, E.C., 1994. The Arctic Ocean and climate: a perspective. In Johannessen, O.M., Muensch, R.D., and Overland, J.E. (Eds.), The Polar Oceans and Their Role in Shaping the Global Environment. Maurice Ewing Ser., 85:5-20.

Bice, K.L., and Marotzke, J., 2001. Numerical evidence against reversed thermohaline circulation in the warm Paleocene/Eocene ocean. J. Geophys. Res., 106(C6):11529-11542. doi:10.1029/2000JC000561

Boltovskoy, D., Kogan, M., Alder, V.A., and Mianzan, H., 2003. First record of a brackish radiolarian (Polycystina): Lophophaena rioplatensis $\mathrm{n}$. $\mathrm{sp}$. in the Rio de la Plata estuary. J. Plankton Res., 25:1551-1559. doi:10.1093/ plankt/fbg107

Hall, J.K., 1979. Sediment waves and other evidence of paleo-bottom currents at two locations in the deep Arctic Ocean. Mar. Geol., 23:269-299.

Jokat, W., Uenzelmann-Neben, G., Kristoffersen, Y., and Rasmussen, T.M., 1992. Lomonosov Ridge-a doublesided continental margin. Geology, 20(10):887-890. doi:10.1130/00917613(1992)020<0887:LRADSC>2.3.CO;2

Jokat, W., Weigelt, E., Kristoffersen, Y., Rasmussen, T., and Schöne, T., 1995. New insights into the evolution of the
Lomonosov Ridge and the Eurasian Basin. Geophys. J. Int., 122:378-392.

Lawver, L.A., and Scotese, C.R., 1990. A review of tectonic models for the evolution of the Canada Basin. In Grantz, A., et al. (Eds.), The Geology of North America (Vol. L): The Arctic Ocean Region: Boulder (Geol. Soc. Am.), 593-618.

Miller, K.G., Kominz, M.A., Browning, J.V., Wright, J.D., Mountain, G.S., Katz, M.E., Sugarman, P.J., Cramer, B.S., Christie-Blick, N., and Pekar, S.F., in press. The Phanerozoic record of global sea-level change. Science.

Myhre, A.M., Eldholm, O., Faleide, J.I., Skogseid, J., Gudlaugsson, S.T., Planke, S., Stuevold, L.M., and Vaagnes, E., 1992. Norway-Svalbard continental margin: structural and stratigraphical styles. In Poag, C.W., and de Graciansky, P.C. (Eds.), Geologic Evolution of Atlantic Continental Rises: New York (Van Nostrand Reinhold), 157185.

Rona, P.A., and Richardson, E.S., 1978. Early Cenozoic global plate reorganization. Earth Planet. Sci. Lett., 40(1):111. doi:10.1016/0012-821X(78)90069-9

Sclater, J.G., Anderson, R.N., and Bell, M.L., 1971. Elevation of ridges and evolution of the central Eastern Pacific. J. Geophys. Res., 76:7888-7915.

Talwani, M., and Eldholm, O., 1977. Evolution of the Norwegian-Greenland Sea. Geol. Soc. Am. Bull., 88:969-999. doi:10.1130/00167606(1977)88<969:EOTNS>2.0.CO;2

Thiede, J., and Eldholm, O., 1983. Speculations about the paleodepth of the Greenland-Scotland Ridge during late Mesozoic and Cenozoic times. In Bott, M.H.P., Saxov, S., Talwani, M., and Thiede, J. (Eds.), Structure and Development of Greenland-Scotland Ridge: New Methods and Concepts. NATO Conf. Ser. IV, 8:445-456.

Thiede, J., and Myhre, A.M., 1996. Introduction to the North Atlantic-Arctic gateways: plate tectonic-paleoceanographic history and significance. In Thiede, J., Myhre, A.M., Firth, J.V., Johnson, G.L., and Ruddiman, W.F. (Eds.), Proc. ODP, Sci. Results, 151: College Station, TX (Ocean Drilling Program), 3-23.

Wright, J.D., 1998. The role of the Greenland-Scotland Ridge in Cenozoic climate change. In Crowley, T.J., and Burke, K. (Eds.), Tectonic Boundary Conditions for Climate Reconstructions: New York (Oxford Univ. Press), 192211.

Wright, J.D., and Miller, K.G., 1996. Control of North Atlantic deep water circulation by the Greenland-Scotland Ridge. Paleoceanography, 11(2):157-170. doi:10.1029/95PA03696

Zachos, J., Pagani, M., Sloan, L., Thomas, E., and Billups, K., 2001. Trends, rhythms, and aberrations in global climate 65 Ma to present. Science, 292:686-693. doi:10.1126/science.1059412

Publication: 7 March 2006 MS 302-105 
Figure F1. Tectonic framework of the Arctic Ocean (after Jackson and Gunnarson, 1990; Jakobsson, 2000). The Gakel Ridge began the rifting of the Lomonosov Ridge at $57 \mathrm{Ma}$, moving it away from the outer continental margin of Siberia and creating the Eurasian Basin. At about the same time, crustal spreading started in the Norwegian-Greenland Sea. Spreading in the Labrador Sea ended at 33 Ma. This may mark the shift in the connection of the Gakel Ridge from the Labrador Sea spreading center to the Norwegian-Greenland spreading center; the Gakel Ridge split the Yermak (Y) and Marion Jessup (MJ) Plateaus at about this time.

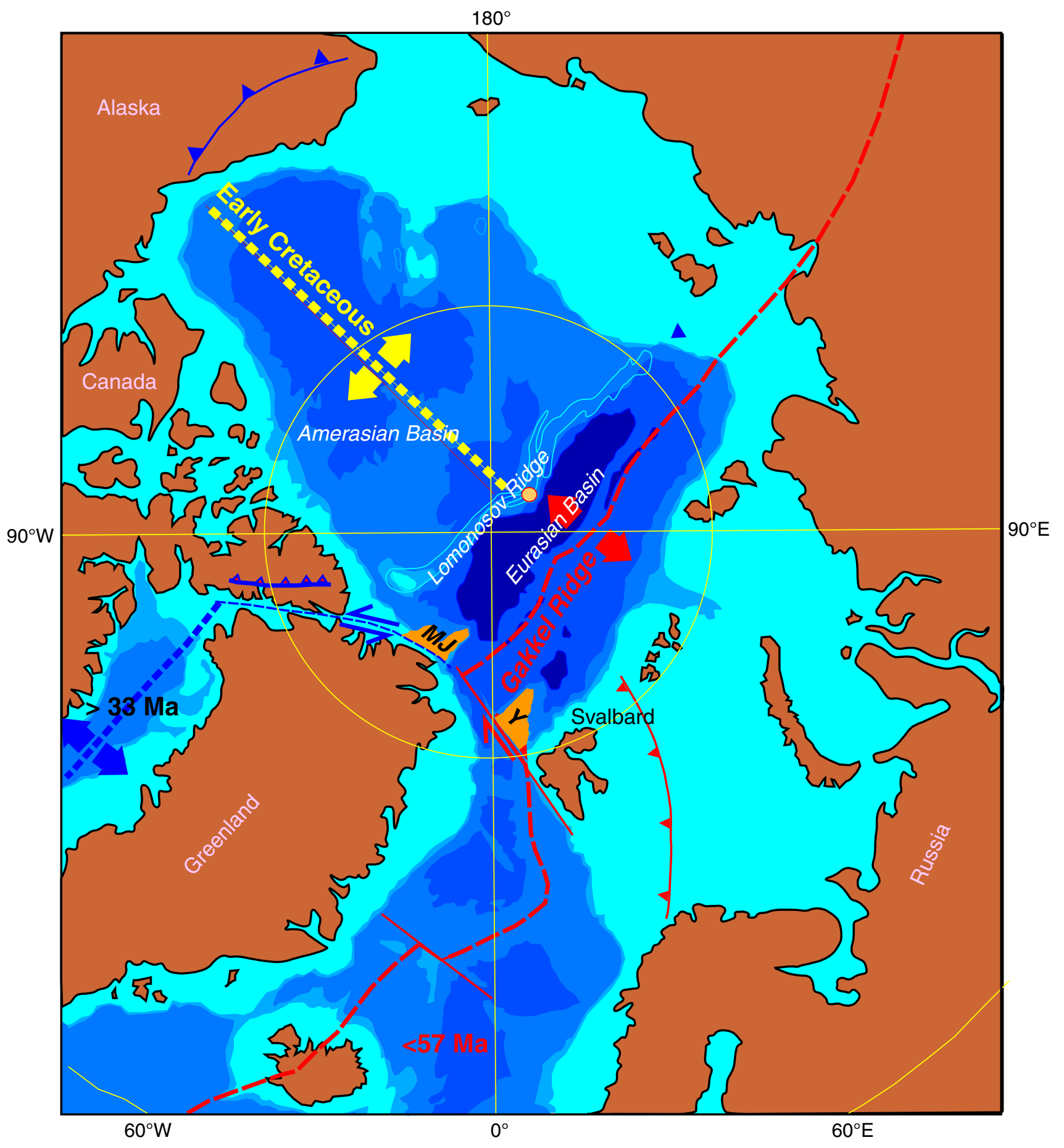


Figure F2. Modeled subsidence of the Lomonosov Ridge assuming simple postrifting (post $54 \mathrm{Ma}$ ) thermal subsidence to modern water depths. The upper (red) subsidence curve shows the subsidence of the ridge without a sediment loading correction. The lower (green) curve shows the subsidence of the sediment surface through time using an Airy correction for sediment loading. Subsidence is calculated relative to present-day sea level; however, an estimate of paleosea level (Miller et al., 2005) is shown at the top of the plot. No correction has been applied to account for variation in loading resulting from variation in sea level. The column at the right of the figure depicts the lithostratigraphic units recovered from the Lomonosov Ridge plotted relative to their age-depth position on the lower subsidence curve.

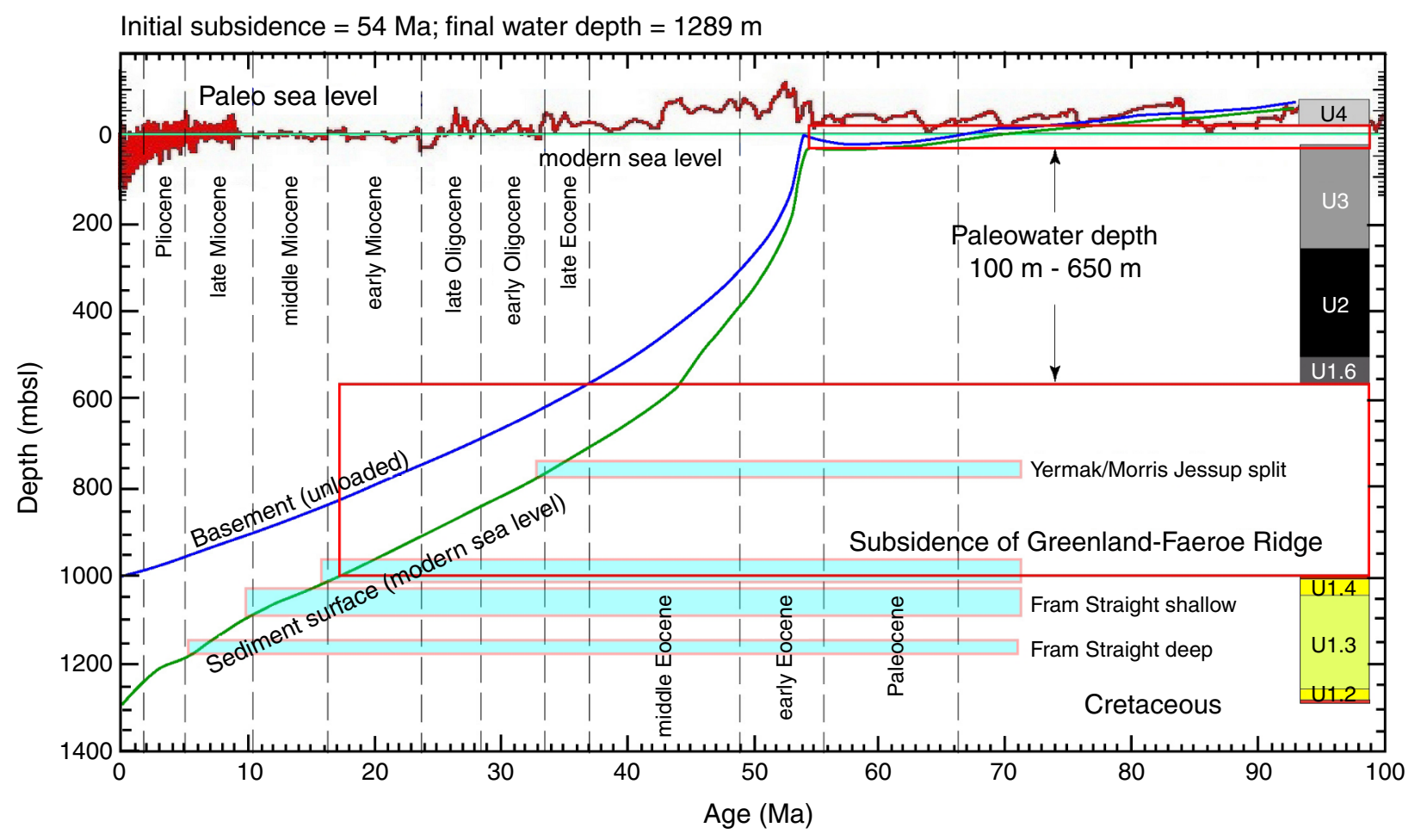

